\title{
ANALISA TINGKAT EFISIENSI ALOKASI AIR IRIGASI D.I. KEDUNGKANDANG MALANG
}

\author{
Dian Dwi Ernawati ${ }^{1}$, Widandi Soetopo. ${ }^{2}$, Moch. Sholichin. ${ }^{2}$ \\ ${ }^{1}$ Staf Dinas PU SDA Provinsi Jawa Timur \\ ${ }^{2}$ Dosen Magister Teknik Pengairan Jurusan Manajemen Sumber Daya Air Universitas Brawijaya \\ email : dian.dwie@yahoo.co.id
}

\begin{abstract}
ABSTRAK : Kebutuhan pengalokasian air di lahan pada setiap wilayah sangatlah berbeda. Salah satu faktor yang dapat menyebabkan perbedaan ini adalah kebiasaan petani di masing-masing daerah dalam mengairi sawahnya. Studi ini difokuskan pada efisiensi pengalokasian air irigasi antara kebutuhan penggenangan dan ketersediaan air pada Daerah Irigasi (DI) Kedungkandang Malang dengan membandingkan antara kebutuhan air yang dihitung berdasarkan metode Faktor Palawija Relatif (FPR) yang biasa diterapkan di Jawa Timur, kebiasaan masyarakat di masing-masing lokasi dalam mengenangi sawahnya di setiap fase pertumbuhan tanaman,dengan pengalokasian debit air pada sawah yang tercatat pada Dinas Sumberdaya Air Provinsi Jawa Timur yang bertanggung jawab atas Tugas Pembantuan Operasi dan Pemeliharaan (TPOP) DI Kedungkandang Malang.Nilai efisiensi rata-rata tiap musim tanam sebesar MT I = 1,20 (kriteria berlebihan), MT II = 1,19 (kriteria berlebihan), MT III $=1,28$ (Kriteria berlebihan). Setelah direncanakan operasi pengendalian pintu maka efisiensi berubah menjadi MT I $=1,051 \approx 1$ (kriteria cukup), MT II $=1,075 \approx 1$ (kriteria cukup), MT III $=1,090 \approx$ (kriteria cukup).
\end{abstract}

Kata kunci : Efisiensi, alokasi air, Irigasi, neraca air, faktor palawija relatif.

Abstract. The need for water allocation in the land in each region is very different. One of the factors that can cause this difference is the farmers' habit in each region in irrigating their fields. This study focuses on balancing the allocation of irrigation water between the inundation requirements and the availability of water in Kedungkandang irrigation area Malang by comparing the water requirements calculated based on the community's customs in each location in winning the rice fields in each phase of plant growth, with the allocation of water discharge on rice fields recorded at the Water Resources Office of East Java Province responsible for the Task of Maintenance of Operation and Maintenance $(T P O P)$ in Kedungkandang irrigation area. The value of the allocation of irrigations each planting seasons $(M T)$ are $M T I=1,20$ (over measure), $M T I I=1,19$ (overmeasure), $M T I I I=1,28$ (over measure). After planed control of the gate, the efficiency change into $M T I=1,051 \approx 1$ (adequate), MT $I I=1,075 \approx 1$ (adequate), MT III $=1,090 \approx$ (Adequate)

Keywords: efficiency, water allocation, irrigations, water balance, palawija relative factor.

Dalam bidang irigasi, faktor utama dalam keberhasilan swasembada pangan di sektor pertanian adalah terpenuhinya kebutuhan air melalui sistem irigasi yang mendukung. Usaha pemerintah untuk mencapai tujuan dalam produksi beras dilakukan dengan intensifikasi produksi padi dan tanaman pangan lain dengan menerapkan teknologi baru dan pemanfaatan lahan potensial untuk meningkatkan produksi. Dalam mencapai tujuan tersebut, pemerintah telah melakukan investasi untuk pengembangan dan rehabilitasi jaringan irigasi, pembinaan pengelolaan irigasi, penyediaansarana produksi modern (Hamdani,1993). 
Dalam bukunya, Suparmoko, 1980 menuliskan bahwa irigasi bermanfaat dalam memperluas areal tanaman, menambah jumlah tanam per tahun dan meningkatkan produktivitas lahan per hektar. Dari sini dapat kita lihat arti penting dari sebuah system irigasi dalam hubungannya dengan peningkatan swasembada pangan.

Pada dasarnya air perlu diatur agar pemberiannya pada lahan tepat jumlah dan waktu (Mustaniroh. 2001). Pada daerah irigasi masalah distribusi air irigasi sering terjadi yaitu apabila besaran debit yang tersedia lebih kecil dari kebutuhan air dilapangan (terutama pada saat musim kemarau), sehingga penggunaan air irigasi secara efisien sangat diperlukan.Hasil produksi irigasi (panen) dipengaruhi bukan saja oleh banyaknya tingkat pemenuhan kebutuhan air, tetapi juga diantaranya oleh cara pemberian air seperti yang dikemukakan oleh Ahmad et al. (2004), Erdem et al. (2006) dan Khan et al.(2005).

Secara umum wilayah Malang Raya (Batu, Kota Malang, dan Kabupaten Malang) merupakan wilayah yang sangat subur. Pada daerah pegunungannya banyak terdapat sungai dan anak-anak sungai yang merupakan sumber daya air permukaan yang sangat besar dimana banyak dimanfaatkan untuk pertanian. Kondisi yang subur ini ternyata sangat berbalik pada daerah Kabupaten Malang arah selatan. Daerah Malang Selatan memiliki tekstur tanah yang subur, datar, dan luas namun kurang memiliki sumberdaya air permukaan yang dapat diandalkan untuk pertanian.

Untuk mengatasi masalah ketersediaan air permukaan irigasi tersebut, maka dibangun sebuah bendung di Sungai Amprong, Kota Malang yang kemudian dikenal sebagai Bendung Kedungkandang, dimana debitnya disuplesi oleh Kali Bango melalui saluran suplisi Kalisari di Kecamatan Kedungkandang, dan Kali Meri di Kecamatan Tangkilsari, Kab. Malang. Adapun debit rata-rata yang tercatat pada DI Kedungkandang adalah sebesar 3,237 m3/detik pada Musim Tanam (MT) I, 3,104 m3/detik pada MT II, dan 2,840 m3/detik pada MT III.

Keterbatasan debit yang tersedia pada DI Kedungkandang menyebabkan pola tanam yang berbeda pada beberapa blok tanam daerah irigasi tersebut seperti yang tertera pada Tabel 1 .
Disamping pola tanam yang berbeda pada blok sekunder, pola gilir juga terjadi pada DI tersebut. Sistem gilir ini terjadi di hilir saluran induk mulai BIK 18 hingga BIK 23. Kondisi gilir yang tercatat tara-rata terjadi pada Musim Tanam III yang dimulai pada bulan Juli hingga Oktober.

Tabel 1 Pola Tata Tanam

\begin{tabular}{cccc}
\hline \multirow{2}{*}{ Sekunder } & I & II & III \\
\cline { 2 - 4 } & Padi-Tebu & Padi-Tebu & Padi-Tebu \\
\hline BIK 1 - BIK 4 & Padi -Tebu & Padi-Tebu & $\begin{array}{c}\text { Polowijo- } \\
\text { Tebu }\end{array}$ \\
\hline BIK 5 - BIK 8 & Padi-Tebu & $\begin{array}{c}\text { Polowijo- } \\
\text { Tebu }\end{array}$ & $\begin{array}{c}\text { Polowijo- } \\
\text { Tebu }\end{array}$ \\
\hline BIK 10-BIK 23
\end{tabular}

Sumber: Dinas PU SDA prov. Jatim

Dari hasil survei pendahuluan yang telah dilaksanakan pada 7 April 2017 diketahui bahwa petugas pintu air (PPA) pada DI Kedungkandang belum memiliki Standart Operating System (SOP) mengenai prosedur pengaturan pintu air. Pola pengaturan yang ada hanya sebatas berdasarkan kebiasaan dan permintaan petani, dimana belum ada perhitungan khusus mengenai pengaturannya yang tepat. Dari hasil survey juga didapatkan beberapa pintu air yang sudah rusak namun tetap beroperasi sehingga debit air yang masuk tidak terukur dengan baik.

Dari data tersebut diatas dapat disimpulkan bahwa terjadi ketidak seimbangan neraca air antara kondisi di hulu saluran berkecukupan air namun kekurangan air di hilirnya, sehingga evaluasi mengenai pengalokasian air guna perbaikan sistem pemberian air perlu dilakukan.

Berdasarkan hal-hal tersebut diatas, maka dapat dirumuskan permasalahan dalam studi ini yaitu :

1. Berapakah debit kebutuhan irigasi pada tiap petak sekunder dengan Metode FPR?

2. Berapakah debit kebutuhan irigasi real lapangan pada tiap petak sekunder

3. Bagaimana tingkat efisiensi pengalokasian air eksisting terhadap kebutuhan air tanaman?

4. Bagaimanakah solusi dari permasalahan pengoperasian alokasi air yang ada?

Untuk mendekati sasaran yang diharapkan maka perlu diadakan pembatasan permasalahan yaitu: 
1. Daerah studi yang akan dijadikan studi kasus dalam studi ini adalah Daerah Irigasi Kedungkandang yang berada lintas di Kabupaten dan Kota Malang.

2. Analisa Kebutuhan air tanaman menggunakan Metode Faktor Palawija Relatif, dan kebutuhan air nyata hasil survei lapangan.

3. Data tanam yang digunakan adalah data tanam 5 (lima) tahun terakhir yakni mulai 2011-2016

4. Analisa kebutuhan irigasi hanya sampai petak sekunder.

5. Tidak membahas kehilangan air irigasi di saluran

6. Tidak membahan analisa ekonomi

Tujuan dari kajian ini adalah untuk menganalisa tingkat efisiensi pengalokasian debit irigasi pada Daerah Irigasi Kedungkandang. Nilai efisiensi ini didapat dengan membandingkan hasil analisa kebutuhan air teoritis berdasarkan:

1. Perhitungan kebutuhan metode Faktor Palawija Relatif (FPR) dimana metode perhitungannya dengan membandingkan kebutuhan air jenis tanaman tertentu dengan kebutuhan air tanaman palawija yang banyak digunakan untuk menghitung kebutuhan air di daerah Jawa Timur,

2. Perhitungan kebutuhan air eksisting berdasarkan pola pemberian air petani setempat,

3. Pola pengoperasian alokasi air eksisting yang tercatat di lapangan.

Hasil perbandingan antara alokasi air dan kebutuhan air yang dihitung melalui metode FPR dan perhitungan kebutuhan nyata ini kemudian ditampilkan dalam sebuah peta efisiensi alokasi irigasi DI Kedungkandang. Pemetaan ini bertujuan untuk memudahkan pembaca dalam melakukan proses analisa selanjutnya, guna perbaikan jaringan irigasi.

Adapun manfaat yang ingin dicapai dari evaluasi ini adalah sebagai sumbangan pemikiran bagi instansi dan kelompok petani terkait mengenai pengalokasian air irigasi sebagai pertimbangan dan perbaikan pola operasi baik pada Daerah Irigasi Kedungkandang sendiri, maupun bagi daerah irigasi lainnya.

\section{BAHAN DAN METODE}

Daerah Irigasi (DI) Kedungkandang Malang merupakan daerah irigasi kewenangan pusat yang memiliki luas $5.155 \mathrm{Ha}$ dimana lokasinya tersebar lintas Kota dan Kabupaten Malang Provinsi Jawa Timur, Indonesia. Pada gambar 1 ditunjukkan posisi Di Kedungkandang terhadap wilayah malang Raya.

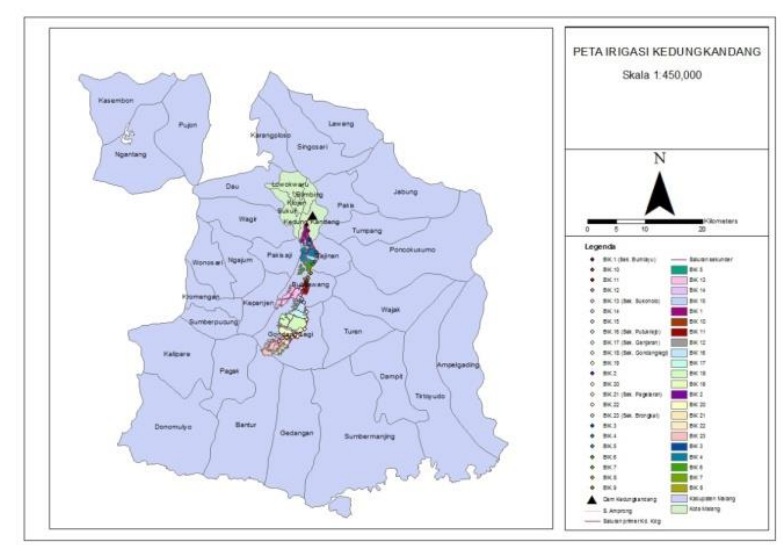

Gambar.1 Peta Lokasi DI Kedungkandang Malang

Secara umum Jaringan Irigasi Kedungkandang terbagi atas 23 sekunder, yakni Bangunan Induk Kedungkandang (BIK) 1-23 dimana untuk BIK 9 yang berada di Kecamatan Krebet Kabupaten Malang dikhususkan untuk memenuhi kebutuhan giling Pabrik Gula (PG) Krebet Malang. Secara topografi wilayah DI Kedungkandang cenderung datar sehingga mudah diolah dan cocok untuk budidaya tanaman padi dan palawija.

Dalam menganalisa suatu permasalahan, diperlukan adanya berbagai data baik itu data primer maupun sekunder. Data primer merupakan data yang diperoleh dari hasil pengamatan dan pengukuran langsung di lapangan, sedangkan data sekunder merupakan data yang diperoleh dari mengutip di berbagai sumber yang dapat dipertanggung jawabkan kebenarannya.

1. Data Primer

- Data dimensi intake saluran sekunder yang diperoleh dari survei lapangan.

2. Data Sekunder

- Data hasil identifikasi petak primer dan sekunder yang diperoleh dari digitasi lokasi. Digitasi ini bertujuan untuk 
memetakan batas wilayah petak sekunder.

- Data realisasi metode pemberian air di lapangan yang didapat dari hasil survey dan wawancara di lapangan. Dari data ini diharapkan dapat diketahui sistem pemberian air yang biasa dilakukan oleh petani, sehingga nantinya dapat dihitung berapa kebutuhan air yang harus disediakan..

- data tanaman Form (04-O) dan skema jaringan irigasi. Data tanam ini merupakan data pencatatan mengenai jumlah dan jenis tanam realisasi di lapangan.

- data pencatatan debit Form (06-O).

- Peta Skema Operasi

Data data ini didapat dari Dinas PU SDA Kabupaten Malang dan Dinas PU SDA Provinsi Jawa Timur.

Untuk menyelesaikan penelitian ini dibuat tahapan-tahapan sebagai berikut:

1. Pengumpulan data primer

- Identifikasi petak sekunder dengan melakukan digitasi lapangan

- Survei dan wawancara lapangan dengan petani setempat mengenai pola pemberian air yang biasa dilakukan, dengan membagikan kuisioner kepada responden di setiap satuan sekunder. Karena kondisi pola pengoperasian petak sekunder yang rata-rata homogen, maka untk tiap sekunder dipilih 5 (lima) orang responden yang dinilai paham mengenai pola pengoperasian serta pemberian air di lapangan.

2. Pengolahan Data Debit

Data debit pada intake DI Kedungkandang merupakan data yang diambil selama masa pengambilan 5 (lima) tahun. Data ini kemudian diolah untuk memperoleh data debit rata-rata pada DI Kedungkandang

3. Perhitungan kebutuhan air di lahan

Kebutuhan air pada tiap petak sekunder didapat berdasarkan 2 (dua) metode perhitungan, yakni:

- Menghitung Kebutuhan air tanaman dengan menggunakan metode Faktor Palawija Relatif (FPR) dihitung berdasarkan rumus berikut:

$$
F P R=\frac{Q}{L P R}
$$

dengan :

$\begin{array}{ll}\text { FPR }= & \begin{array}{l}\text { Faktor Palawija Relatif } \\ (1 / \text { det } / \text { ha.pol })\end{array} \\ \mathrm{Q}= & \begin{array}{l}\text { Debit yang mengalir di sungai } \\ \text { (1/det) }\end{array} \\ \text { LPR }= & \text { Luas Palawija Relatif (ha.pol) }\end{array}$

Tabel 2. Koefisien Pembanding LPR

\begin{tabular}{|l|c|}
\multicolumn{1}{|c|}{ Jenis Tanaman } & Koefisien Pembanding \\
\hline Palawija & 1 \\
Padi Rendeng & 20 \\
a. Persemaian / pembibitan & 6 \\
b. Garap / pengolahan tanah & 4 \\
c. Pertumbuhan / pemeliharaan & 1 \\
Padi Gadu ijin & \\
Padi Gadu tidak ijin & 1,5 \\
Tebu & 0 \\
a. Bibit / muda & 1 \\
b. Tua & 3 \\
Tembakau / Rosela & \\
Pengisian tambak (sawah tambak) & \\
\hline
\end{tabular}

Sumber : DPU Tingkat I Jawa Timur, 1997 dalam Huda (2012)

Luas palawija relatif didapatkan dengan mengalikan luas tanam berdasarkan data tanam masing-masing sekunder dengan faktor palawija relatif(Huda, 2012). Data yang dihitung adalah data tanam selama 5 tahun, hasil perhitungan tiap tahunnya kemudian dirata-rata untuk memperloleh debit kebutuhan metode FPR rerata

4. Menghitung kebutuhan realisasi lapangan dimana data ketinggian genangan tiap fase tanam diperoleh dari survei lapangan. Adapun analisa kebutuhan air di tiap petak sekunder dihitung dengan menggunakan rumus (Departemen Pertanian, 1977):

$$
\begin{aligned}
& Q_{1}=\frac{H \times A}{T} \times 10.000 \\
& Q_{2}=\frac{Q_{1}}{86400} \times \frac{1000}{(1-L)}
\end{aligned}
$$

dengan ;

Q1 = Kebutuhan harian air di petak sawah (m3/hr)

$\mathrm{H}=$ Tinggi genangan $(\mathrm{m})$

A = Luas area sawah (ha)

$\mathrm{T}=$ Interval pemberian air (hari)

Q2 = Kebutuhan harian air pada pintu pemasukan (1/det) 
L = Kehilangan air di lapangan/petak sawah dan saluran

5. Plotting hasil perhitungan kebutuhan air tiap petak sekunder dengan data pengoperasian alokasi air pada peta hasil digitasi identifikasi lokasi.

6. Evaluasi alokasi air irigasi dengan membandingkan antara pengalokasian air eksisting dengan kebutuhan air riil di lapangan

$$
\begin{aligned}
& \text { Eff }=\frac{Q_{\text {Alokasi }}}{Q_{\text {FPR }}} \\
& \text { Eff }=\frac{Q_{\text {Alokasi }}}{\text { Qnyata }_{\text {nat }}} \\
& \text { dengan : } \\
& \mathrm{Q}_{\text {Alokasi }}=\text { Debit alokasi pada intake (1/det) } \\
& \mathrm{Q}_{\mathrm{FPR}}=\text { Debit kebutuhan air metode FPR } \\
& \text { (1/dtk) } \\
& \mathrm{Q}_{\text {Nyata }}=\text { Debit kebutuhan air nyata } \\
& \text { lapangan (1/dtk) }
\end{aligned}
$$

Hasil perhitungan tiap tahunnya kemudian dirata-rata untuk memperloleh nilai efisiensi alokasi air rata-rata, yang kemudian diklasifikasikan dengan kriteria berikut:

Tabel 3. Kriteria Efisiensi Alokasi Air

\begin{tabular}{|c|c|}
\hline Efisiensi Alokasi & Kriteria \\
\hline$<0,9$ & Kurang \\
\hline $1,1<1>0,9$ & Cukup \\
\hline$>1,1$ & Berlebihan \\
\hline
\end{tabular}

\section{HASIL DAN PEMBAHASAN}

\section{Kebutuhan Air Metode FPR}

Kebutuhan air metode FPR sangat tergantung dari pola tanam dan ketersediaan debit di lapangan.Dalam studi ini data debit yang diambil pada intake bangunan sekunder selama 5 (lima) tahun terakir. Data ini kemuadian diratarata untuk mendapatkan nilai rerata alokasi air pada setiap sekunder dalam liter per detik, yang kemudian ditotal untuk setiap sekundernya guna memperoleh debit rerata seluruh daerah irigasitiap musim tanam yaitu; Q $\mathrm{QTI}_{\text {TI }}$ sebesar 3237,599 1/dt, Q MTII sebesar 3104,4861/dt, dan $\mathrm{Q}_{\text {MTIII }}$ sebesar 2840,267 1/dt.

Debit rerata tiap musim tanam ini kemudian digunakan untuk mencari nilai FPR masingmasing sekunder dengan menggunakan persamaan (1) untuk setiap masa tanam dalam kurun waktu 5 (lima) tahun. Hasil tersebut kemudian diperoleh nilai kebutuhan air FPR rata-rata tiap musim tanam yaitu: $\mathrm{Q}_{\text {MTI }}$ sebesar 2695,011 1/dt, Q Q $\mathrm{Q}_{\text {MTIII }}$ sebesar 2531,394 1/dt.

\section{Kebutuhan Air Nyata di Lahan}

Sebelum melakukan survei lapangan terlebih dahulu dilakukan digitasi untuk menentukan batas wilayah tiap sekunder. Hasil dari gititasi tersebut dapat dilihat pada gambar 3 .

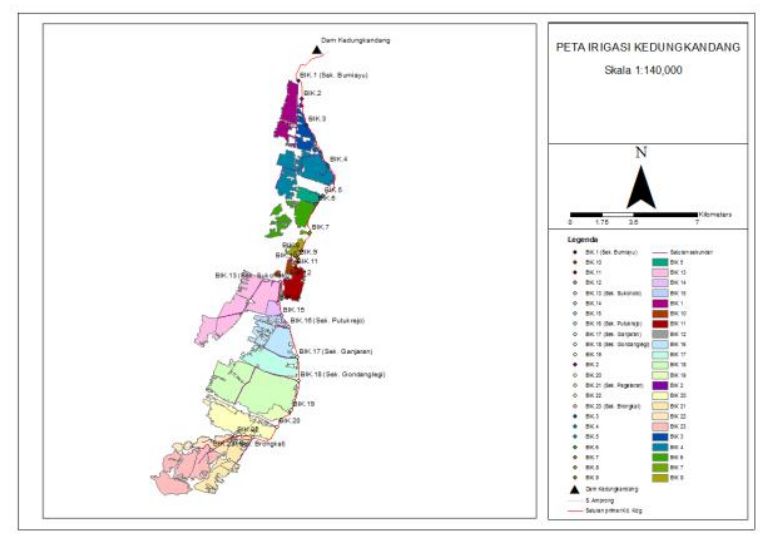

Gambar 2. Peta Irigasi DI Kedungkandang

Dari hasil wawancara pada kuesioner dapat diketahui bahwa dari rata-rata petani yang diwawancarai memiliki pengalaman usaha tani sedang yakni 10-20 tahun dengan rata-rata status penguasaan lahan sebagai penggarap dan penyewa. Dari 110 responden tersebut, sebanyak $95,45 \%$ dari para responden tidak mengetahui tentang Rencana Tata Tanam Global (RTTG), sehingga merekapun tidak menanami sawahnya sesuai dengan pola RTTG yang telah ditetapkan. Pola tanam yang selama ini diterapkan lebih didasarkan pada kultur dan kebiasaan yang ada pada masyaraakat setempat.

Adapun pola tata tanam yang dilakukan oleh masyarakat setempat berdasarkan kuesioner yang telah disebarkan dapat dilihat pada Tabel 4 Realisasi Pola tanam Pada DI Kedungkandang. Dari tabel tersebut dapat dilihat bahwa didalam DI Kedungkandang terdapat 4 (empat) blok sekunder yang memiliki pola tanam berbeda.

Pada hulu DI Kedungkandang yakni BIK 1 hingga BIK 8 petani setempat cenderung menerapkan pola tanam Padi - Padi - Padi disamping tanaman tebu yang ditanam selama satu tahun. Pola tanam tersebut dimungkinkan 
pada daerah tersebut karena ketersediaan debit yang cukup tinggi di wilayah sekunder tersebut

Semakin ke hilir maka dapat dilihat bahwa pola tanam berubah mengikuti ketersediaan air di wilayah tersebut. Pada MT III petani cenderung tidak menanam padi namun menanam tebu dan palawija karena ketersediaan debit yang ada berkurang dan tidak mencukupi apabila ditanam padi.

\begin{tabular}{|c|c|c|c|}
\hline \multicolumn{2}{|c|}{ Realisasi Pola Tanam } & $\begin{array}{l}\text { Persentase } \\
(\%)\end{array}$ & Lokasi \\
\hline $\mathrm{a}$ & Padi - Padi - Padi & 36.17 & $\begin{array}{l}\text { BIK 1, BIK 2, BIK 3, } \\
\text { BIK 4, BIK 5, BIK 6, } \\
\text { BIK 7, BIK } 8\end{array}$ \\
\hline b & $\begin{array}{l}\text { Padi - Padi - } \\
\text { Palawija }\end{array}$ & 8.51 & BIK 10, BIK 11 \\
\hline $\mathrm{c}$ & $\begin{array}{l}\text { Padi-Palawija- } \\
\text { Palawija }\end{array}$ & 2.13 & BIK 12 \\
\hline $\mathrm{d}$ & $\begin{array}{l}\text { Pola tanam yang } \\
\text { lain } \\
\text { Palawija-Tebu }\end{array}$ & 53.19 & $\begin{array}{l}\text { BIK 13, BIK 14, BIK } \\
\text { 15, BIK 16, BIK 17, } \\
\text { BIK 18, BIK 19, BIK } \\
20, \text { BIK 21, BIK 22, } \\
\text { BIK } 23\end{array}$ \\
\hline
\end{tabular}

Dari hasil kuesioner diketahui pula bahwa sebanyak $61 \%$ responden menyatakan pernah mengalami kekurangan air sehingga harus mengalami gilir terutama pada bulan Juli hingga Oktober. Adapun pola penggenangan lahan pada masing-masing wilayah sekunder sedikit berbeda, bergantung pada ketersediaan air serta kultur dan budaya masyarakat setempat dalam bertani. Adapun pola pemberian air rata-rata berdasarkan hasil kuesioner pada DI kedungkandang dapat kita lihat pada Tabel 5. Tinggi Genangan Tiap Fase Tanam.

Dari data tinggi genangan tiap fase tanam ini kemudian dihitung kebutuhan air nyata lapangan pada DI Kedungkandang dengan menggunakan persamaan (2) dan (3), sehingga didapatkan nilai kebutuhan air nyata lapangan. Rerata kebutuhan nyata lapangan tiap musim tanam pada DI kedungkandang adalah

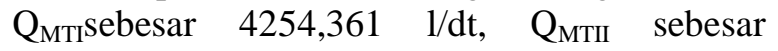
3894,411 1/dt 1/dt, dan $\mathrm{Q}_{\text {MTIII }}$ sebesar 3107,084 $1 / \mathrm{dt}$.

Tabel 5 Tinggi Genangan Tiap Fase Tanam

\begin{tabular}{|c|c|c|c|}
\hline & Fase Tanam & $\begin{array}{l}\text { Tinggi } \\
\text { Genangan } \\
(\mathrm{cm})\end{array}$ & $\begin{array}{c}\text { Persentase } \\
(\%)\end{array}$ \\
\hline 1 & Fase Penanaman Bibit & 2 & 86.36 \\
\hline 2 & $\begin{array}{l}10 \text { hari mulai hari ke } 4 \\
\text { hingga hari ke } 14\end{array}$ & 10 & 72.73 \\
\hline 3 & $\begin{array}{l}\text { Fase } 14 \text { hari penanaman } \\
\text { padi mulai hari ke- } 15 \\
\text { hingga hari ke- } 30\end{array}$ & 7 & 54.55 \\
\hline 4 & $\begin{array}{l}\text { Fase } 5 \text { hari setelah } \\
\text { pemupukan ke- } 2 \text { dan } \\
\text { menyiangi ke-1: }\end{array}$ & 2 & 4.91 \\
\hline 5 & $\begin{array}{l}\text { Fase } 14 \text { hari setelah hari } \\
\text { ke- } 35 \text { hinnga hari ke- } \\
50 \text { : }\end{array}$ & 5 & 68.18 \\
\hline 6 & $\begin{array}{l}\text { Fase } 5 \text { hari setelah } \\
\text { pemupukan ke- } 3 \text { dan } \\
\text { menyiangi ke-2 }\end{array}$ & 2 & 50 \\
\hline 7 & $\begin{array}{l}\text { Fase setelah hari ke-55 } \\
\text { hingga berbunga dan } \\
\text { terisi penuh }\end{array}$ & 10 & 54.55 \\
\hline 8 & $\begin{array}{l}\text { Fase } 7 \text { hari hingga } 10 \\
\text { hari sebelum panen }\end{array}$ & 0 & 100 \\
\hline
\end{tabular}

Apabila kita bandingkan maka grafik rata-rata debit alokasi air, debit kebutuhan air metode FPR dan kebutuhan air nyata tanaman dalam satu tahun dapat kita lihat pada gambar 3 Grafik Perbandingan Alokasi Air Kebutuhan Air Metode FPR dan Kebutuhan Air Nyata Lapangan dimana jelas terlihar kebutuhan nyata nilainya jauh diatas kebutuhan metode FPR.

\section{Nilai Efisiensi Alokasi Air}

Nilai efisiensi alokasi dihitung dengan membandingkan alokasi air dengan kebutuhan air metode FPR dan kebutuhan nyata lapangan. Hasil perhitungan nilai efisiensi pada Tabel 6 berikut. 


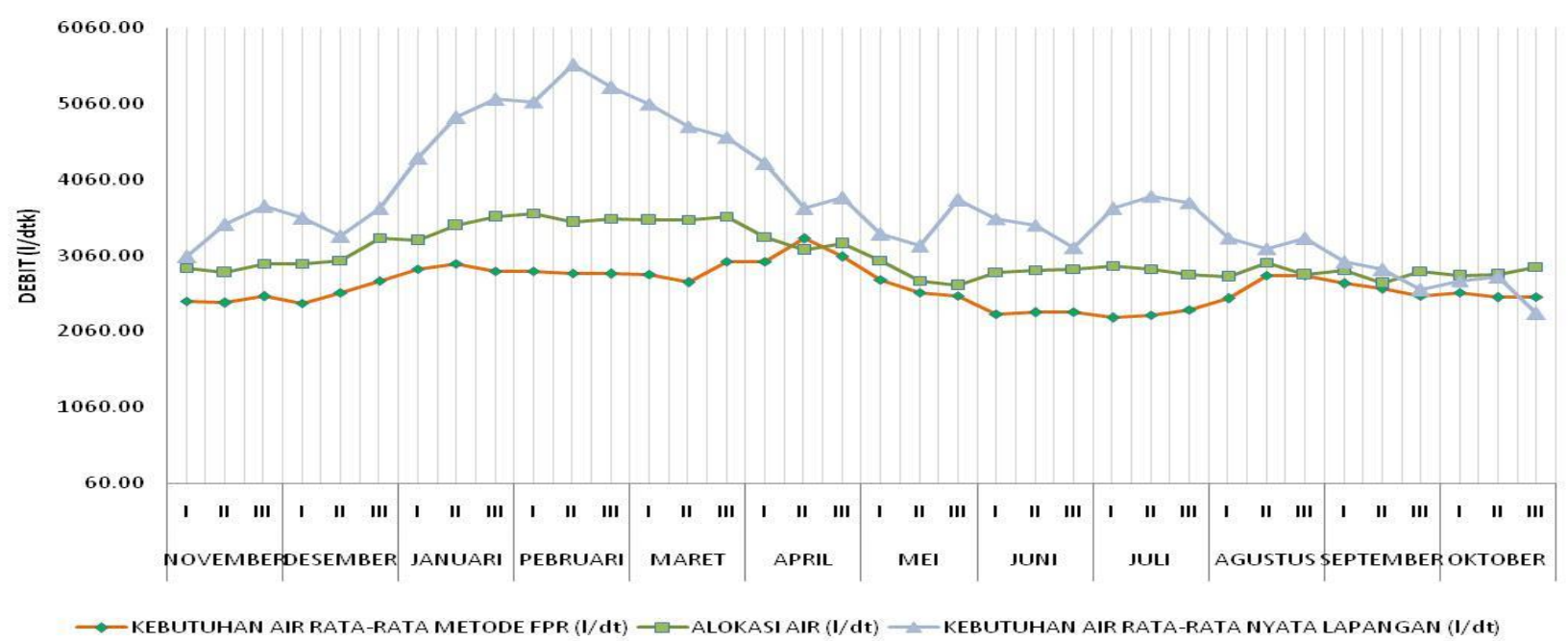

Gambar 3. Perbandingan Alokasi Air Kebutuhan Air Metode FPR dan Kebutuhan Air Nyata Lapangan

Tabel 6. Rekapitulasi Kriteria Alokasi Irigasi

\begin{tabular}{|c|c|c|c|c|}
\hline \multirow{2}{*}{ Sekunder } & \multicolumn{2}{|c|}{$\begin{array}{c}\text { Efisiensi Alokasi terhadap } \\
\text { KebutuhanAir Metode FPR }\end{array}$} & \multicolumn{2}{c|}{$\begin{array}{c}\text { Efisiensi Alokasi terhadap } \\
\text { Kebutuhan Air Nyata }\end{array}$} \\
\cline { 2 - 5 } & Nilai & Kriteria & Nilai & Kriteria \\
\hline BIK 1 & 1.218 & berlebihan & 1.113 & berlebihan \\
\hline BIK 2 & 2.651 & berlebihan & 1.168 & berlebihan \\
\hline BIK 3 & 1.320 & berlebihan & 1.162 & berlebihan \\
\hline BIK 4 & 0.978 & cukup & 0.799 & kurang \\
\hline BIK 5 & 1.065 & berlebihan & 0.894 & kurang \\
\hline BIK 6 & 1.016 & cukup & 0.786 & kurang \\
\hline BIK 7 & 1.479 & berlebihan & 0.959 & cukup \\
\hline BIK 8 & 1.233 & berlebihan & 1.060 & berlebihan \\
\hline BIK 10 & 1.213 & berlebihan & 0.861 & kurang \\
\hline BIK 11 & 1.268 & berlebihan & 1.147 & berlebihan \\
\hline BIK 12 & 1.218 & berlebihan & 1.065 & berlebihan \\
\hline BIK 13 & 1.490 & berlebihan & 0.853 & kurang \\
\hline BIK 14 & 1.558 & berlebihan & 1.163 & berlebihan \\
\hline BIK 15 & 1.880 & berlebihan & 1.688 & berlebihan \\
\hline BIK 16 & 1.525 & berlebihan & 1.087 & berlebihan \\
\hline BIK 17 & 1.135 & berlebihan & 1.072 & berlebihan \\
\hline BIK 18 & 1.204 & berlebihan & 1.012 & cukup \\
\hline BIK 19 & 1.277 & berlebihan & 0.947 & kurang \\
\hline BIK 20 & 1.796 & berlebihan & 1.063 & berlebihan \\
\hline BIK 21 & 2.235 & berlebihan & 1.800 & berlebihan \\
\hline BIK 22 & 1.798 & berlebihan & 1.571 & berlebihan \\
\hline BIK 23 & 1.667 & berlebihan & 0.908 & kurang \\
\hline
\end{tabular}


Hasil analisa ini kemudian diploting pada peta hasil digitasi untuk mempermudah analisa. Dari gambar 4 dan 5dapat diamati bahwa pada beberapa sekunder nilai efisiensi antara alokasi air dibandingkan dengan kebutuhan air FPR dan alokasi air dibandingkan dengan kebutuhan nyata sangat berbeda. Perbedaan ini dapat disebabkan antara lain karena perhitungan nilai kebutuhan nyata sangat tergantung dari pola pengelolaan air oleh petani setempat, sedangkan nilai kebutuhan FPR merupakan nilai perbandingan kebutuhan air antara jenis tanaman satu dengan jenis tanaman lainnya dengan

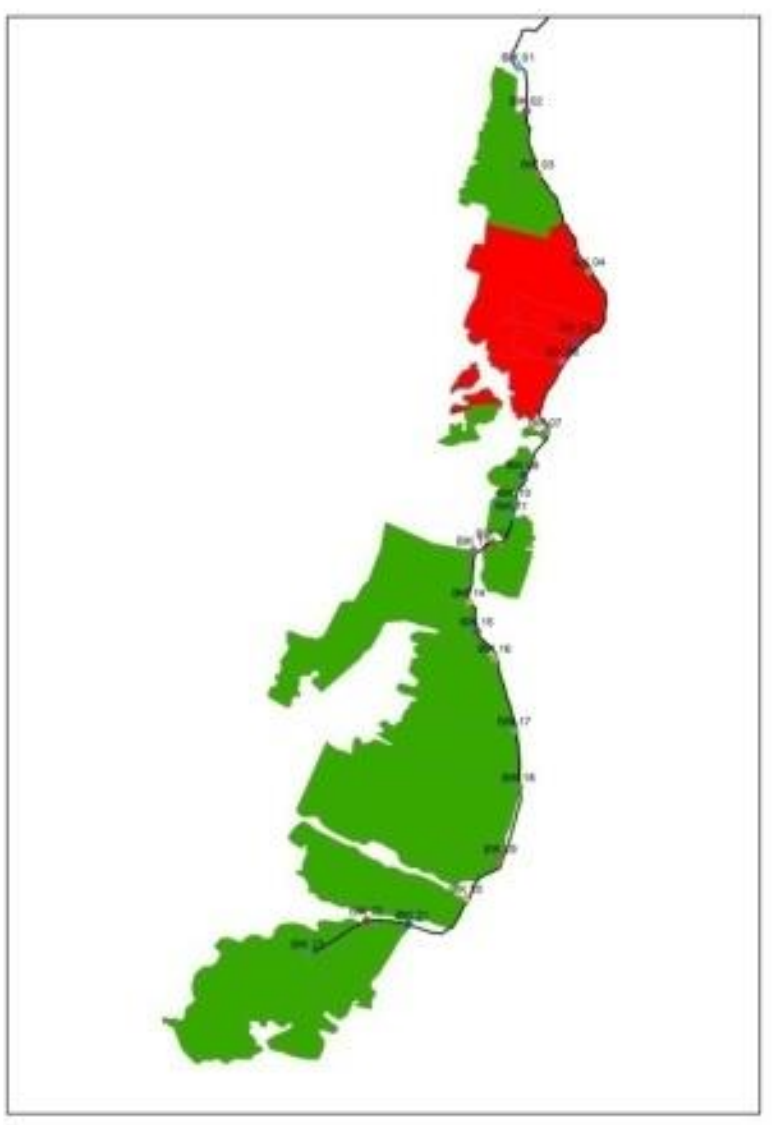

tanaman pembanding palawija yang dijadikan acuan

Hal lain yang dapat kita amati dalam analisa ini adalah pola tanam yang cenderung berubah pada musim tanam III di daerah irigasi ini. Seperti yang kita ketahui MT III yakni bulan Juli-Oktober merupakan musim kemarau dengan debit air yang rata-rata turun. Kekurangan debit ini disikapi oleh petani setempat, terutama petani di bagian hilir, untuk tidak menanam padi namun berganti menanam palawija, sehingga intensitas tanam padi berkurang. Kondisi ini tentu juga menyebabkan kebutuhan air pada MT III berkurang.
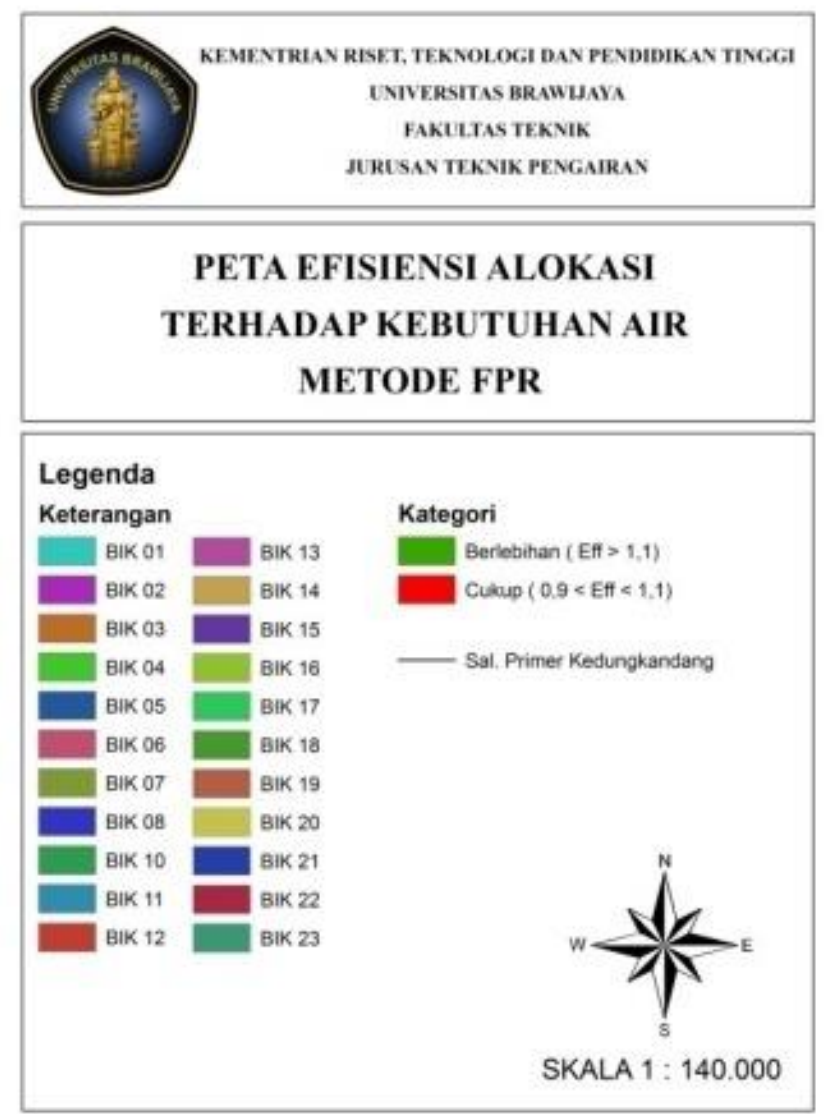

Gambar 4. Peta Efisiensi Alokasi Air Terhadap Kebutuhan Air metode FPR 

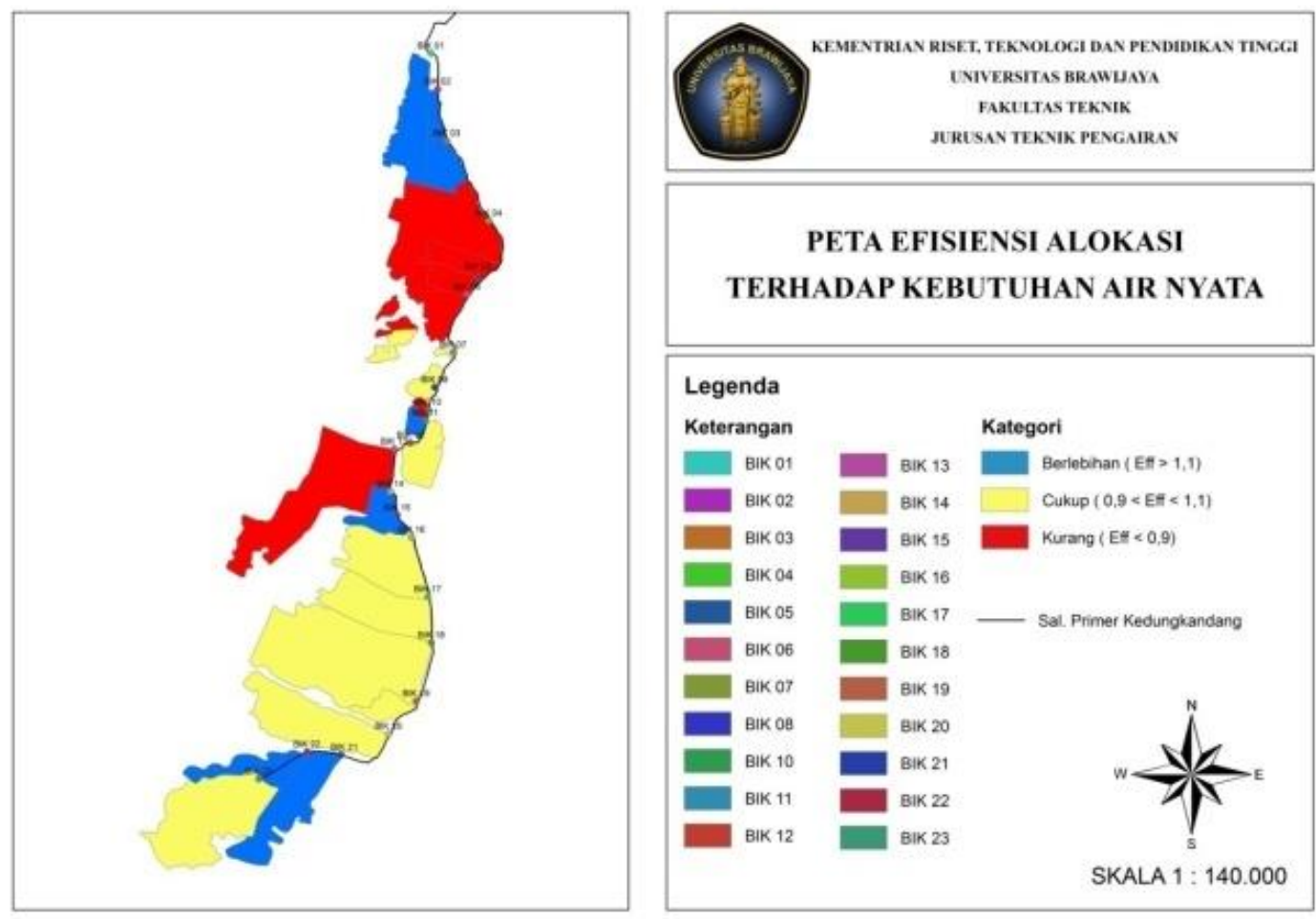

Gambar 5 Peta Efisiensi Alokasi Air Terhadap Kebutuhan Air Nyata

Berdasarkan hal tersebut diatas dapat disimpulkan apabila nilai efisiensi pada sekunder bagian hilir cukup ataupun berlebih, bukan karena ketersediaan air di hulu induk kedungkandang cukup, namun lebih dikarenakan intensitas tanam padi yang menurun. Dengan pengelolaan operasi pintu yang efisien kita juga berharap kelebihan air di hulu dapat dimanfaatkan di hilir untuk lebih meningkatkan intensitas tanam padi pada DI Kedungkandang tersebut.

Meskipun kondisi kurang efisien alokasi air ini hanya terjadi di beberapa sekunder namun untuk mengatasi masalah tersebut penanganannya haruslah terintegrasi mulai dari sekunder di hulu hingga sekunder di hilir. Apabila pengalokasian air di hulu sudah berlebihan maka sudah dipastikan bagian hilir pasti kekurangan air, oleh karena itu operasi pintu yang tepat merupakan salah satu solusi untuk mengatasi permasalahan ini.

\section{KESIMPULAN}

1. Debit rata-rata kebutuhan air pada Daerah Irigasi Kedungkandang dengan metode FPR periode 2012-2016 tiap musim tanam adalah:
- $\quad$ MT I $=2695,011 \mathrm{l} / \mathrm{dt}$

- $\quad$ MT II $=2714,837 \mathrm{l} / \mathrm{dt}$

- $\quad$ MT III $=2531,394 \mathrm{l} / \mathrm{dt}$

Besarnya nilai kebutuhan air dengan metode FPR sangat tergantung dari ketersediaan air serta pola tanam yang dilakukan oleh petani setempat. Kebutuhan air dengan metode FPR tersebut masih dapat dipenuhi oleh alokasi debit yang ada, dimana alokasi debit rata-rata pada periode tertersebut adalah:

- $\quad$ MT I $=3237,599 \mathrm{l} / \mathrm{dt}$

- $\quad$ MT II $=3104,4861 / \mathrm{dt}$

- $\quad$ MT III $=2840,267 \mathrm{l} / \mathrm{dt}$

2. Debit rata-rata kebutuhan irigasi nyata lapangan Daerah Irigasi Kedungkandang periode 2012-2016 tiap musim tanam adalah:

- $\quad$ MT I $=4254,361 \mathrm{l} / \mathrm{dt}$

- $\quad$ MT II $=3894,4111 / \mathrm{dt}$

- $\quad$ MT III = 3107,084 l/dt

Besarnya nilai kebutuhan nyata ini sangat tergantung dari kultur dan kebiasaan masyarakat setempat dalam menggenangi sawahnya. Kebutuhan air nyata lapangan tersebut nilainya berada diatas alokasi air 
yang ada, dimana artinya terjadi kekurangan air pada daerah irigasi tersebut.

3. Tingkat efisiensi alokasi air irigasi rata-rata tiap musim tanam pada DI kedungkandang adalah:

- Efisiensi alokasi air terhadap kebutuhan air metode FPR (Eff $\left.f_{\mathrm{FPR}}\right)$

- MT I $=1,20>>$ Kriteria berlebihan

- $\mathrm{MT}$ II $=1,19>>$ Kriteria berlebihan

- $\mathrm{MT}$ III $=1,28>>$ Kriteria berlebihan

Nilai efisiensi alokasi ini menunjukkan bahwa debit alokasi air lebih besar dari pada kebutuhan air tanaman yang dihitung berdasarkan metode FPR, yang artinya terdapat kemungkinan bahwa sebagaian dari debit alokasi terbuang.

- Efisiensi alokasi terhadap kebutuhan air nyata lapangan ( Eff $\left._{\text {Nyata }}\right)$

- MT I =0,76 >> Kriteria kurang

- $\mathrm{MT}$ II $=0,80>>$ Kriteria kurang

- $\quad$ MT III =0,91 > Kriteria cukup

Nilai efisiensi alokasi ini menunjukkan bahwa debit alokasi air lebih kecil dari pada kebutuhan air nyata tanaman, yang artinya terdapat kemungkinan bahwa ada kondisi gilir pemberian air pada daerah irigasi tersebut.

\section{SARAN}

Dalam studi ini data ketinggian genangan dilapangan hanya didapatkan melalui survei pola ketinggian genangan oleh petani dengan membagikan kuesioner. Dari data ini kemudian diolah untuk memperoleh debit kebutuhan lapangan.

Hasil dari survei menunjukkan masingmasing daerah memiliki pola penggenangan yang berbeda pada setiap fase tanam. Dengan adanya perbedaan pola pemberian air ini maka perlu adanya kalibrasi lapangan guna menguatkan hasil survey yang telah dilakukan.

Kalibrasi lapangan yang disarankan tidak perlu dengan mengukur ketinggian genangan disetiap petak sawah. Kalibrasi dapat dilakukan dengan mengukur langsung ketinggian genangan pada beberapa petak sawah yang dipilih dan dianggap mampu mewakili daerahnya. Hasil pengukuran langsung ini kemudian dibandingkan dengan hasil survey untuk memperoleh data ketinggian genangan tiap fase tanam yang lebih kuat.

Kesimpulan lain yang dapat diambil dari studi ini adalah apabila nilai efisiensi pada sekunder bagian hilir cukup ataupun berlebih, bukan karena ketersediaan air di hulu induk kedungkandang cukup, namun lebih dikarenakan intensitas tanam padi yang menurun. Untuk meningkatkan intensitas tanam, salah satu cara yang dapat dipertimbangkan adalah dengan pengaturan pola operasi pintu di masing-masing sekunder. Dengan pengaturan pola operasi pintu diharapkan debit air dapat terdistribusi secara tepat dan efisien sehingga intensitas tanam maningkat.

\section{DAFTAR PUSTAKA}

Departemen Pertanian. 1977. Pedoman Bercocok Tanam Padi Palawija Sayur-sayuran. Jakarta.

Erdem, T., Erdem, Y., Orta, H., \& Okursoy, H., 2006, Water-Yield Relationships of Potato under Different Irrigation Methods and Regimens, Journal of Science and Agriculture, 63 (3), 226-231.

Hamdani.1993. Prospek Pemanfaatan Irigasi Riam Kanan untuk Pengembangan Pertanian Pangan di Kal-Sel. Tesis S2. PPSUGM. Yogyakarta

Huda, Nurul. 2012. Kajian Sisitem Pemberian Air Irigasi Sebagai Dasar Penyusunan Jadwal Rotasi Pada Daerah Irigasi Tumpang Kabupaten Malang. Skripsi tidak dipublikasikan. Malang: Universitas Brawijaya

Khan, M.H., \& Saleem, N., 2005, Influence of Different Irrigation Intervals on Growth and Yield of Bell Pepper, Research Journal of Agriculture and Biological Science, 1(2), 125-128.

Siti Asmaul Mustaniroh. 2001. Evaluasi Aspek Kelembagaan Pengelolaan Jaringan Irigasi Di Tingkat Petani Pada Usahatani Padi Sawah Di Kabupaten Banjarbaru, Kalimantan Selatan. Jurnal Teknologi Pertanian Universitas Brawijaya, Vol. 2, No. 2, AgustuS 2001 : 14-21

Suparmoko.1980. Pengembangan Pengairan dalam Strategi Pangan. Prisma No.10 hal 37-47. LP3ES. Jakarta. 